\title{
Urological injuries in the civil war of Libya
}

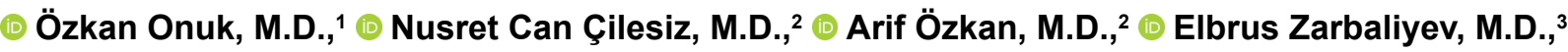 \\ (1) Nurten Dayığlu, M.D., ${ }^{4}$ (i) Barış Nuhoğlu, M.D. ${ }^{1}$
}

\begin{abstract}
${ }^{1}$ Department of Urology, Yeniyüzyıl University Faculty of Medicine, İstanbul-Turkey
${ }^{2}$ Department of Urology, Taksim Training and Research Hospital, İstanbul-Turkey

${ }^{3}$ Department of General Surgery, Yeniyüzyıl University Faculty of Medicine, İstanbul-Turkey

${ }^{4}$ Department of Biostatistics, Yeniyüzyıl University Faculty of Medicine, İstanbul-Turkey
\end{abstract}

\begin{abstract}
BACKGROUND: In this article, we aimed to evaluate results of patients who acquired various injuries during Libya civil war who then were transferred to our facility with genitourinary trauma for further assessment and treatment.

METHODS: A total of 121 wounded patients, including 21 (I7.3\%) with I or more combined urogenital injuries, were treated at Yeni Yüzyıl University Private Gaziosmanpaşa Hospital from October 2014 to September 2016.

RESULTS: Of the 21 patients, 13 (6I.9\%) were injured by explosive weapons, while the rest 8 (38.I\%) had bullet wounds. The 2 I urogenital injuries were to the kidney in 7 cases (33.4\%), ureter in 5 (23.8\%), bladder in $5(23.8 \%)$, scrotum in 2 (9.5\%), and penis in 2 (9.5\%). There was associated damage to organs other than the urogenital system in 21 patients (I00\%). Two patients had nephrectomies performed on-site medical facility. The rest of patients had no urogenital organ resections. Urogenital trauma had higher rates of liver damage, generalized infection, blood transfusions, and longer hospital stay.
\end{abstract}

CONCLUSION: Knowing that war related surgery patients should be approached as a distinct and non-standard category, every case must be evaluated individually. Patients should be evaluated in a multidisciplinary approach and physicians should be aware of infections affecting morbidity and mortality.

Keywords: Multiple trauma; urogenital trauma; war surgery; war-related trauma.

\section{INTRODUCTION}

The Libyan Civil War consumed the nation from February 2011 to 2018 and became a living hell for most of its public. Until now there is no precise data on the number of people directly injured during this war. Injuries to urogenital organs account for around $1 \%$ to $10 \%$ of all war injuries and mostly are associated with multiple traumas, especially abdominal ones. ${ }^{[1-3]}$ In these patients, it may be difficult to decide which surgical procedure has priority resulting in delayed identification of urogenital or other organ damage. ${ }^{[4]}$ In spite of having all the wounded transported to the nearest hospitals in the area it is usual that there is a lack of highly specialized medical staff and technical opportunities. After necessary stabiliza- tion, this leads to transportation of these patient populations to the closest reference centers where needed imaging and multidisciplinary approach should be provided.

In this article, we aimed to evaluate results of patients who acquired various injuries during Libya Civil War who then were transferred to our facility with genitourinary (GU) trauma for further assessment and treatment.

\section{MATERIALS AND METHODS}

After approval the institutional review board 121 wounded patients included in this study. In this cohort, including 21 (I7.3\%) with one or more urogenital injuries, were treated

Cite this article as: Onuk Ö, Çilesiz NC, Özkan A, Zarbaliyev E, Dayığlu N, Nuhoğlu B. Urological injuries in the civil war of Libya. Ulus Travma Acil Cerrahi Derg 2022;28:90-93.

Address for correspondence: Özkan Onuk, M.D.

Yeniyüzyıl Üniversitesi Tıp Fakültesi, Üroloji Anabilim Dalı, İstanbul, Turkey

Tel: +90 212 - 48I 4058 E-mail: drozkanonuk@gmail.com

Ulus Travma Acil Cerrahi Derg 2022;28(1):90-93 DOI: 10.14744/tjtes.2020.5729I Submitted: 26.01.2019 Accepted: 17.09.2020

Copyright 2022 Turkish Association of Trauma and Emergency Surgery 
at Yeni Yüzyıl University Private Gaziosmanpasa Hospital in from October 2014 to September 2016. All patients their first intervention performed in Libya. Complicated patients having no opportunity to be treated in Libya were transported in our facility by plane. According to the leading injury patients were hospitalized by general surgery or orthopedics and traumatology. Patients requiring advanced life support were directly hospitalized to intensive care unit (ICU). All multiple trauma patients had computed tomography performed. All the necessary imaging was performed in cases of extremity injuries. Patients' progress was recorded on the daily basis. Patients having GU trauma were consulted by our department. After needed diagnostics patients who already had their first intervention were performed secondary surgery.

\section{Statistical Analysis}

Distribution of variables was obtained using the Kolmogorov-Smirnov test. The Mann-Whitney $U$ test was utilized for analyses of the independent quantitative data. For the analyses of independent categorical data, the Chi-square test was preferred, and when it was not applicable, Fischer's exact test was substituted.

\section{RESULTS}

Of the 21 patients, $13(61.9 \%)$ were injured by explosive weapons, while the rest $8(38.1 \%)$ had bullet wounds. The 2 I urogenital injuries were to the kidney in 7 cases $(33.4 \%)$, ureter in 5 (23.8\%), bladder in 5 (23.8\%), scrotum in 2 (9.5\%), and penis in 2 (9.5\%), There was associated damage to organs other than the urogenital system in 21 patients $(100 \%)$.

Six of these 21 patients had urological procedures performed. Two patients had nephrectomies performed on-site medical facility. The rest of patients had no urogenital organ resections. Two of the patients underwent ureteral end-toend anastomosis. In addition, two patients underwent open bladder repair (double suture repair). Four of those six had simultaneous orthopedic procedures, one had neurosurgical intervention. One patients 15 other patients had various degrees of complex procedure which required general surgery, orthopedics, otorhinolaryngology and neurosurgery Of the 21 patients, six were hospitalized to ICU due to need for appropriate resuscitation. Twelve out of $2 \mathrm{I}$ patients had indications for blood transfusion at the admission to our facility. Fifteen of 21 patients had been detected to have methicillin resistant Staphylococcus aureus growth in blood samples. Nine of twenty one had Acinetobacter baumannii, five had Pseudomonas aeruginosa, six had Klebsiella pneumoniae, two had Enterobacter spp., and three patients had Enterococcus spp. growth in blood samples.

In terms of age, serum creatinine level and $C$ reactive protein (CRP) there was no statistically significant difference between groups having and having no urogenital trauma. Hospital stay showed to be longer in the group having uro-

Table I. Comparison of characteristics between two groups

\begin{tabular}{lccc}
\hline & Urogenital injury (+) $(\mathbf{n}=\mathbf{2 1})$ & Urogenital injury (-) (n=99) & p-value* $^{*}$ \\
\hline Age (years) & $26.76 \pm 8.69$ & $29.56 \pm 8.51$ & 0.1212 \\
Length of hospital (month) & $33.33 \pm 24.78$ & $16.66 \pm 19.80$ & $0.0003^{*}$ \\
C-reactive protein & $114.63 \pm 79.97$ & $99.26 \pm 96.72$ & 0.2218 \\
Serum creatinine & $0.98 \pm 0.12$ & $0.88 \pm 0.09$ & 0.158 \\
\hline
\end{tabular}

"Mann-Whitney U Test.

Table 2. Comparison of other injuries and complications between two groups

\begin{tabular}{lccc}
\hline & Urogenital injury (+) $(\mathbf{n = 2 1 )}(\mathbf{\%})$ & Urogenital injury (-) (n=99) (\%) & p-value $^{*}$ \\
\hline Type of injury Gunshot/Burst & $38.1 / 61.9$ & $50.5 / 49.5$ & 0.3013 \\
Liver injury (+) & 38.1 & 6.1 & $0.0005^{* *}$ \\
Splenectomy (+) & 4.8 & 3.0 & 0.5417 \\
Bowel injury (+) & 33.3 & 20.2 & 0.2484 \\
Abdominal trauma (+) & 100.0 & 67.7 & $0.0023^{* *}$ \\
Infection (+) & 71.4 & 34.3 & $0.0016^{* * *}$ \\
Blood transfusion (+) & 57.1 & 17.2 & $0.0001^{* * *}$ \\
Intensive care unit & 28.6 & 8.1 & $0.0168^{* *}$ \\
\hline
\end{tabular}

${ }^{* *}$ Fisher'sExact Test; ${ }^{* * * *}$ PearsonChi-Square. 
genital trauma $(p=0.0003)$ (Table I). Group having urogenital trauma had higher rates of simultaneous liver injury $(p=0.0005)$, abdominal trauma $(p=0.0023)$, generalized infection $(p=0.0016)$, blood transfusion $(p=0.000 \mathrm{I})$, and ICU requirement $(p=0.0168)$ (Table 2$)$.

\section{DISCUSSION}

It is well known that management of the patients injured during weapon conflicts requires truly multidisciplinary approach providing combined and coordinated work of physicians representing different branches. The profile of injuries during Libyan civil war was similar to the profile, we observed during other known conflicts like the Afghan conflict where most combined trauma patients had pelvic and genital injuries. $^{[5-9]}$ Several reviews have been published on the experience with urologic injuries in the Croatian war. ${ }^{[10-13]}$ Vuckovic et al. ${ }^{[13]}$ demonstrated that renal and ureteral injuries constituted $47 \%$ of the war injuries, and injuries of the bladder, urethra, and external genitalia occurred in $17.2 \%, 4.6 \%$, and $30.8 \%$, respectively. The University Hospital at Rebro reported that 1350 war casualties were treated with a $4.4 \%$ incidence of urologic injuries; these included $35 \%$ to the kidney, $15 \%$ ureter, $11.6 \%$ bladder, $3.3 \%$ urethra, $25 \%$ testes, and $10 \%$ penis. ${ }^{[10]}$ In a review of war injuries to the ureter in Croatia, another institution found a $2.6 \%$ incidence of urologic injury among 4425 wounded patients, of which $9.5 \%$ involved the ureters. ${ }^{[12]}$ Our rates of ureteral injury were found to be higher with \%17.3.

Rober et al. ${ }^{[14]}$ reported the contribution of damage to the bladder to urogenital injuries in war to be $8 \%$ to $20 \%$ while rate of bladder injuries in our study lies in this range with $23.8 \%$. The distribution of reported injuries in Vietnam for kidney, ureters, bladder, prostate, urethra, penis, and scrotum was $31 \%, 3.6 \%, 14.7 \%, 3.2 \%, 8.9 \%, 16.2 \%$, and $25.4 \%$, respectively. The higher rate of scrotal and testicle injuries than in the previous conflicts is likely because of the wide use of explosive weapons. ${ }^{\left[{ }^{[]}\right.}$Our study shows similar rates but true rates can be different due to the fact that not all the consecutive patients were transported to our facility.

As shown in the literature the injuries of external genitalia are common due to high incidence rate of injuries in the scrotal area. Penile injury was found to be $16 \% .^{[15]}$ The rate of incidence was similar to that reported during the Vietnam War, that is, $18 \%{ }^{[3]}$ External genital injuries should have high incidence due to wider use of aviation bombs and shrapnel like armament. Accepting the lack of primary data in our study rates of scrotal-penile trauma of $11 \%$ could indicate rare use of above spoken weaponry. Historically, ureteral injuries due to external trauma are infrequent, involving $1 \%$ of all GU tract trauma and are usually associated with injury to other major abdominal organs. ${ }^{[16]}$ Our rates with $23.8 \%$ seem to be far outweighing literature rates which can be explained by generally higher severity of trauma patients transferred to our facility. Most common intra-abdominal impairments associated with injuries to the kidneys, ureter, and bladder were including large and small intestine, stomach, and duodenum. As a consequence management of this group of patients requires more attention.

To the best of our knowledge, there are no sufficient data on infectious complications related to war related injuries. Still, infections complicating injuries are known for its high contribution in morbidity and mortality. In the literature, there has been no comment on infections of war injured patients in related studies. Persisting and resistant infectious complications lengthen the hospital stay and should be timely suspected and meticulously evaluated. ${ }^{[15]}$

The limitations of the study were that not all consecutive patients were evaluated in our center and that the heterogeneity of the cohort weakened due to its distance from the war zone. In contrast to the previous studies, we found infections to be very important in mortality and morbidity of the patients. The presence of resistant infections prolonged hospitalization of patients and increased morbidity and mortality. Therefore, it is very important to evaluate war injured patients in terms of resistant infections.

\section{Conclusions}

War surgery being complex and unpredictable in its nature, requires multidisciplinary approach which should focus on not only primary trauma but probable and potentially life-threatening complications like wound infections.

Ethics Committee Approval: This study was approved by the Yeni Yuzyil University Faculty of Medicine Clinical Research Ethics Committee (Approval number: 14.1 1.2017/042, date: 09.1 I.2017).

Peer-review: Internally peer-reviewed.

Authorship Contributions: Concept: Ö.O.; Design: Ö.O.; Supervision: Ö.O.; Materials: A.Ö., E.Z.; Data: A.Ö., E.Z.; Analysis: N.C.Ç., E.Z., N.D.; Literature search: N.C.Ç., E.Z., N.D.; Writing: Ö.O., N.C.Ç., B.N.; Critical revision: A.Ö., N.D., B.N.

Conflict of Interest: None declared.

Financial Disclosure: The authors declared that this study has received no financial support.

\section{REFERENCES}

1. Salvatierra O Jr., Rigdon WO, Norris DM, Brady TW. Vietnam experience with 252 urological war injuries. J Urol 1969;101:615-20. [CrossRef]

2. Ochsner TG, Busch FM, Clarke BG. Urogenital wounds in Vietnam. J Urol 1969;101:224-5. [CrossRef]

3. Serkin FB, Soderdahl DW, Hernandez J, Patterson M, Blackbourne L, Wade CE. Combat urologic trauma in US military overseas contingency operations. J Trauma 2010;69 Suppl 1:S175-8. [CrossRef]

4. McAninch JW, Carroll PR. Renal exploration after trauma. Indications 
and reconstructive techniques. Urol Clin North Am 1989;16:203-12.

5. Mossadegh S, Midwinter M, Parker P. Developing a cumulative anatomic scoring system for military perineal and pelvic blast injuries. J R Army Med Corps 2013;159 Suppl 1:140-4. [CrossRef]

6. Williams M, Jezior J. Management of combat-related urological trauma in the modern era. Nat Rev Urol 2013;10:504-12. [CrossRef]

7. Clemens MS, Janak JC, Rizzo JA, Graybill JC, Buehner MF, Hudak SJ, et al. Burns to the genitalia, perineum, and buttocks increase the risk of death among U.S. service members sustaining combat-related burns in Iraq and Afghanistan. Burns 2017;43:1120-8. [CrossRef]

8. Abu-Zidan FM, Al-Tawheed A, Ali YM. Urologic injuries in the Gulf War. Int Urol Nephrol 1999;31:577-83. [CrossRef]

9. Cetti NE. War injuries during the Gulf War: Experience of a teaching hospital in Kuwait. Ann R Coll Surg Engl 1995;77:156-7.
10. Marekovic Z, Derezic D, Krhen I, Kastelan Z. Urogenital war injuries. Mil Med 1997;162:346-8. [CrossRef]

11. Tucak A, Lukacevic T, Kuvezdic H, Petek Z, Novak R. Urogenital wounds during the war in Croatia in 1991/1992.J Urol 1995;153:121-2. [CrossRef]

12. Tucak A, Petek Z, Kuvezdic H. War injuries of the ureter. Mil Med 1997;162:344-5. [CrossRef]

13. Vuckovic I, Tucak A, Gotovac J, Karlovic B, Matos I, Grdovic K, et al. Croatian experience in the treatment of 629 urogenital war injuries. J Trauma 1995;39:733-6. [CrossRef]

14. Rober PE, Smith JB, Pierce JM Jr. Gunshot injuries of the ureter. J Trauma. 1990;30:83-6. [CrossRef]

15. Herr HW. Urological Injuries in the Civil War.J Urol 2004;172:1800-4.

16. Kunkle DA, Kansas BT, Pathak A, Goldberg AJ, Mydlo JH. Delayed diagnosis of traumatic ureteral injuries. J Urol 2006;176:2503-7. [CrossRef]

\title{
ORIJINAL ÇALIŞMA - ÖZ
}

\section{Libya sivil savaşında gerçekleşen ürolojik yaralanmalar \\ Dr. Özkan Onuk, ${ }^{1}$ Dr. Nusret Can Çilesiz, ${ }^{2}$ Dr. Arif Özkan, ${ }^{2}$ Dr. Elbrus Zarbaliyev, ${ }^{3}$ \\ Dr. Nurten Dayıoğlu, ${ }^{4}$ Dr. Barış Nuhoğlu ${ }^{1}$}

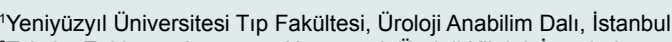

${ }^{2}$ Taksim Eğitim ve Araştırma Hastanesi, Üroloji Kliniği, İstanbul

${ }^{3}$ Yeniyüzyıl Üniversitesi Tıp Fakültesi, Genel Cerrahi Anabilim Dalı, İstanbul

${ }^{4}$ Yeniyüzyıl Üniversitesi Tıp Fakültesi, Biyoistatistik Anabilim Dalı, İstanbul

AMAÇ: Bu makalede Libya sivil savaşında genitoüriner yaralanma sonrası ileri inceleme ve tedavi amacıyla tarafımıza transfer edilen hastaların tedavi sonuçlarını değerlendirmeyi ve sunmayı amaçladık.

GEREÇ VE YÖNTEM: Bir ya da daha fazla kombine 21 (\%।7.3) ürogenital yaralanması olan hasta olmak üzere toplam I2I yaralı hasta, Ekim 20।4Eylül 2016 arasında Yeni Yüzyıl Üniversitesi Özel Gaziosmanpaşa Hastanesi’nde tedavi edildi.

BULGULAR: Yirmi bir hastanın I3'ünde (\%6।.9) patlayıcı silahlar, \%8'inde (\%38. I) mermi yaraları vardı. Yirmi bir hastanın yedisinde böbrek yaralanması (\%33.4), beşinde (\%23.8) üreteral yaralanma, beşinde (\%23.8) mesane yaralanması, ikisinde (\%9.5) skrotum, ikisinde (\%9.5) penis yaralanması saptandı. Ürogenital sistem dışındaki organ yaralanmaları 2 I hastanın tamamında eşlik etmekteydi. Böbrek yaralanması olan iki hastada nefrektomi yapıldı. Geri kalan hastalarda ürogenital organ rezeksiyonu yapılmadı. Ürogenital travma oranının karaciğer hasarı, genel enfeksiyon, kan transfüzyonu ve uzamış hastane yatışından daha fazla olduğu saptandı.

TARTIŞMA: Savaşla ilişkili cerrahi hastalarının ayrı ve standart olmayan bir kategori olarak ele alınması gerektiğini bilerek, her olgu ayrı ayrı değerlendirilmelidir. Hastalar multidisipliner bir yaklaşımla değerlendirilmeli ve doktorlar morbidite ve mortaliteyi etkileyen enfeksiyonların farkında olmalıdır. Anahtar sözcükler: Multipl travma; savaş cerrahisi; savaşla ilişkili travma; ürogenital travma.
\end{abstract}

Ulus Travma Acil Cerrahi Derg 2022;28(I):90-93 doi: 10.14744/tjtes.2020.5729| 